\title{
Sweet taste of heavy water
}

Natalie Ben $\mathrm{Abu}^{1+}$, Philip E. Mason ${ }^{2+}$, Hadar Klein ${ }^{1}$, Nitzan Dubovski ${ }^{1}$, Yaron Ben Shoshan-Galeczki ${ }^{1}$, Einav Malach ${ }^{1}$, Veronika Pražienková ${ }^{2}$ Lenka Maletínská ${ }^{2}$, Carmelo Tempra $^{2}$, Victor Cruces Chamorro ${ }^{2}$, Josef Cvačka ${ }^{2}$, Maik Behrens ${ }^{3}$, Masha Y. Niv ${ }^{*}$ and Pavel Jungwirth ${ }^{2 *}$

${ }^{1}$ The Institute of Biochemistry, Food Science and Nutrition, The Robert H Smith Faculty of Agriculture, Food and Environment, 76100 Rehovot, Israel and The Fritz Haber Center for Molecular Dynamics, The Hebrew University of Jerusalem, 91904 Jerusalem, Israel, ${ }^{2}$ Institute of Organic Chemistry and Biochemistry, Czech Academy of Sciences, Flemingovo nám. 2, 16610 Prague 6, Czech Republic, and ${ }^{3}$ Leibniz-Institute for Food Systems Biology at the Technical University of Munich, Lise-Meitner-Str. 34, 85354 Freising, Germany.

${ }^{+}$Both authors contributed equally.

*Corresponding authors: masha.niv@mail.huji.ac.il and pavel.jungwirth@uochb.cas.cz

Abstract:

Hydrogen to deuterium isotopic substitution has only a minor effect on physical and chemical properties of water and, as such, is not supposed to influence its neutral taste. Here we conclusively demonstrate that humans are, nevertheless, able to distinguish $\mathrm{D}_{2} \mathrm{O}$ from $\mathrm{H}_{2} \mathrm{O}$ by taste. Indeed, highly purified heavy water has a distinctly sweeter taste than same-purity normal water and adds to perceived sweetness of sweeteners. In contrast, mice do not prefer $\mathrm{D}_{2} \mathrm{O}$ over $\mathrm{H}_{2} \mathrm{O}$, indicating that they are not likely to perceive heavy water as sweet. HEK 293 T cells transfected with the TAS1R2/TAS1R3 heterodimer and chimeric G-proteins are activated by $\mathrm{D}_{2} \mathrm{O}$ but not by $\mathrm{H}_{2} \mathrm{O}$. Lactisole, which is a known sweetness inhibitor acting via the TAS1R3 monomer of the TAS1R2/TAS1R3, suppresses the sweetness of $\mathrm{D}_{2} \mathrm{O}$ in human sensory tests, as well as the calcium release elicited by $\mathrm{D}_{2} \mathrm{O}$ in sweet taste receptor-expressing cells. The present multifaceted experimental study, complemented by homology 
modelling and molecular dynamics simulations, resolves a long-standing controversy about the taste of heavy water, shows that its sweet taste is mediated by the human TAS1R2/TAS1R3 taste receptor, and opens way to future studies of the detailed mechanism of action.

\section{One sentence summary:}

Heavy water elicits sweet taste for humans via the TAS1R2/TAS1R3 taste receptor.

\section{Main:}

Heavy water, $\mathrm{D}_{2} \mathrm{O}$, has fascinated researchers since the discovery of deuterium by Urey in $1931(1,2)$. The most notable difference in physical properties between $\mathrm{D}_{2} \mathrm{O}$ and $\mathrm{H}_{2} \mathrm{O}$ is the roughly $10 \%$ higher density of the former liquid, which is mostly a trivial consequence of deuterium being about twice as heavy as hydrogen. A more subtle effect of deuteration is the formation of slightly stronger hydrogen (or deuterium) bonds in $\mathrm{D}_{2} \mathrm{O}$ as compared to $\mathrm{H}_{2} \mathrm{O}(3,4)$. This results in a small increase of the freezing and boiling points by $3.8^{\circ} \mathrm{C}$ and $1.4^{\circ} \mathrm{C}$, respectively, and in a slight increase of 0.44 in $\mathrm{pH}$ (or $\mathrm{pD}$ ) of pure water upon deuteration(5). In comparison, a mere dissolution of atmospheric $\mathrm{CO}_{2}$ and subsequent formation of dilute carbonic acid in open containers has a significantly stronger influence on the $\mathrm{pH}$ of water, changing it by more than one unit(6).

Biological effects are observable for high doses of $\mathrm{D}_{2} \mathrm{O}$. While bacteria or yeasts can function in practically pure $\mathrm{D}_{2} \mathrm{O}$, albeit with somewhat hindered growth rate(7-9), for higher organisms damaging effects on cell division and general metabolism occur at around $25 \%$ deuteration, with lethal conditions for plants and animals typically occurring at $~ 40$ $50 \%$ deuteration of the body water $(2,10,11)$. Small levels of deuteration are, nevertheless, 
harmless. This is understandable given the fact that about 1 in every 6400 hydrogens in nature is found in its stable isotope form of deuterium(12). Oral doses of several milliliters of $\mathrm{D}_{2} \mathrm{O}$ are safe for humans $(13)$ and are being routinely used together with another stable isotopic form of water, $\mathrm{H}_{2}{ }^{18} \mathrm{O}$, for metabolic measurements in clinical praxis(14). Probably the best-established effect of $\mathrm{D}_{2} \mathrm{O}$ is the increase of the circadian oscillation length upon its administration to both animals and plants. This has been attributed to a general slowdown of metabolism upon deuteration, although the exact mechanism of this effect is unknown $(15,16)$.

A long-standing unresolved puzzle concerns the taste of heavy water. There is anecdotal evidence from the 1930 s that the taste of pure $\mathrm{D}_{2} \mathrm{O}$ is distinct from the neutral one of pure $\mathrm{H}_{2} \mathrm{O}$, being described mostly as "sweet"(17). However, Urey and Failla addressed this question in a short article published in Science in 1935 concluding authoritatively that upon tasting "neither of us could detect the slightest difference between the taste of ordinary distilled water and the taste of pure heavy water"(18). This had, with a rare exception(19), an inhibitive effect on further human studies, with research concerning effects of $\mathrm{D}_{2} \mathrm{O}$ focusing primarily on animal or cell models. Experiments in animals indicated that rats developed aversion toward $\mathrm{D}_{2} \mathrm{O}$ when deuteration of their body water reached harmful levels, but there is conflicting evidence to whether they can taste heavy water or use other cues to avoid it $(20,21)$.

Within the last two decades, the heterodimer of the taste receptor of the TAS1Rs type of G-protein coupled receptors (GPCRs), denoted as TAS1R2/TAS1R3, was established as the main receptor for sweet taste(22). The human TAS1R2/TAS1R3 heterodimer recognizes diverse natural and synthetic sweeteners(23). The binding sites of the different 
bioRxiv preprint doi: https:/doi.org/10.1101/2020.05.22.110205. this version posted June 15,2020 . The copyright holder for this preprint (which was not certified by peer review) is the author/funder, who has granted bioRxiv a license to display the preprint in perpetuity. It is made available under aCC-BY-NC-ND 4.0 International license.

types of sweeteners include an orthosteric site (a sugar-binding site in the extracellular Venus flytrap domain of TAS1R2) and several allosteric sites, including sites in the extracellular regions of the TAS1R2 and TAS1R3 subunits and in the transmembrane domain of TAS1R3(24, 25) (Figure 1). Additional pathways for sweet taste recognition have also been suggested, involving glucose transporters and ATP-gated $\mathrm{K}+\operatorname{channel}(26,27)$.

Interestingly, not all artificial sweeteners are recognized by rodents(28). Differences in human and rodent responses to tastants, as well as sweetness inhibitors such as lactisole, have been useful for delineating the molecular recognition mechanism of sweet compounds - using human-mouse chimeric receptors, it was shown that the transmembrane domain (TMD) of human TAS1R3 is required for the activating effects of cyclamate(29) and for the inhibitory effect of lactisole(30).

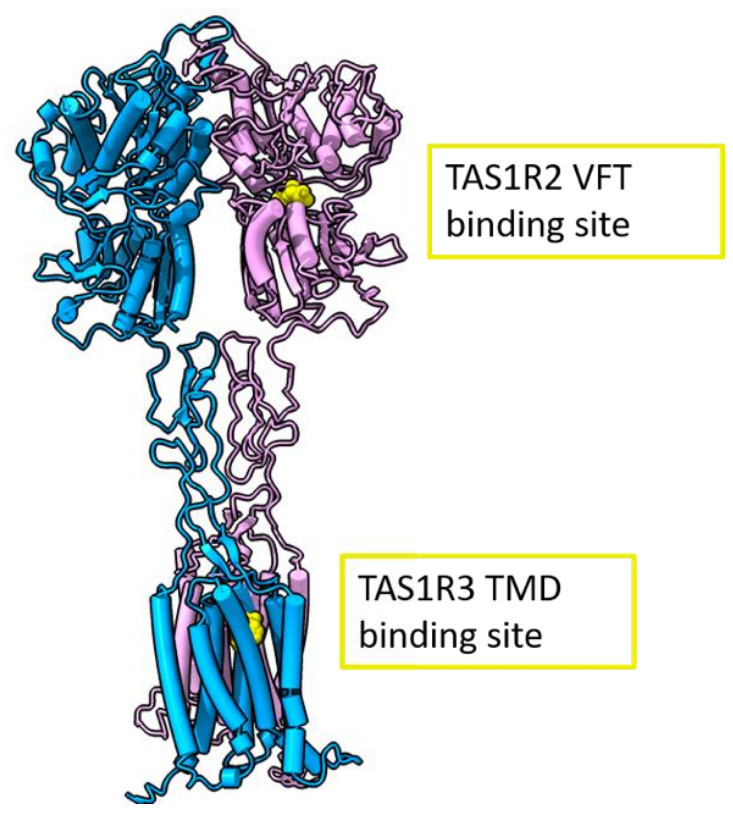

Figure 1. Full human sweet taste TAS1R2/TAS1R3 receptor model with the TAS1R2 monomer colored in pink and the TAS1R3 monomer in cyan. Binding sites are represented in yellow. The full receptor heterodimer was prepared with the I-Tasser web server(31) based on multiple published structures (i.e. 6N51, 5X2M, and 5K5S). The structures were aligned to a Metabotropic Glutamate Receptor 5 Cryo-EM structure (PDB: 6N51) and minimized using Schrödinger Maestro 2019-1. The binding site of TAS1R2 is based on coordinates of docked D-glucose to a Venus flytrap (VFT) model 
that was previously validated (32) (modeling based on template PDB ID: 5X2M, docking performed with Schrödinger Maestro 2019-1, Glide XP), and the TAS1R3 binding site is based on a lactisole molecule docked to the TAS1R3 TMD model (template PDB IDs: 4OR2 and 4OO9, Schrödinger Maestro 2018-2, Glide SP). The figure was made using ChimeraX (version 0.93)(33).

A combination of TAS1R3 with another member of the TAS1R family, TAS1R1, results in a dimer that mediates umami taste, elicited by molecules such as glutamate or its sodium salt form of monosodium glutamate (MSG)(34). Bitter taste is mediated by the taste receptors type 2 (TAS2R) gene family(35), a branch of Family A GPCRs(24). The human genome has 25 TAS2R subtypes and over a thousand of bitter compounds are currently known(36), with numerous additional bitter tastants predicted (37).

In this study, we systematically address the question of sweet taste of heavy water by a combination of sensory experiments in humans, behavioral experiments in mice, tests on sweet taste receptor-transfected cell lines, and computational modeling including molecular dynamics (MD) simulations. This combined approach consistently leads to a conclusion that the sweet taste of pure $\mathrm{D}_{2} \mathrm{O}$ is a real effect for human subjects due to activation of the TAS1R2/TAS1R3 sweet taste receptor. While present simulations show, in accord with previous experiments(38), that proteins are systematically slightly more rigid and compact in $\mathrm{D}_{2} \mathrm{O}$ than in $\mathrm{H}_{2} \mathrm{O}$, the specific molecular mechanism of the heavy water effect on the TAS1R2/TAS1R3 receptor remains to be established.

\section{Water purity}

We have paid great attention to the purity of the water samples, further degassing and redistilling under vacuum the purest commercially available $\mathrm{D}_{2} \mathrm{O}$ and $\mathrm{H}_{2} \mathrm{O}$. The lack of non-negligible amounts of organic impurities was subsequently confirmed by gas 
chromatography with mass spectrometry analysis and by experiments with water samples at different levels of purification, see Supporting Material (SM). This is extremely important - note in this context that "the vibrational theory of olfaction", which suggested distinct perception of deuterium isotopes of odorants due to difference in their vibrational spectra(39), has been refuted with some of the observed effects turning out to be due to impurities $(40,41)$.

\section{Experiments with a human sensory panel}

A human sensory panel was employed to study the $\mathrm{D}_{2} \mathrm{O}$ taste. Triangle tests based on two samples of $\mathrm{H}_{2} \mathrm{O}$ and one sample of $\mathrm{D}_{2} \mathrm{O}$ (or vice versa), with random success rate of one third, were presented to the panelists in a randomized order. Panelists were asked to pick the odd sample out - to smell only, to taste only (with a nose clips), or to taste with open nose. Our results show that humans perceive $\mathrm{D}_{2} \mathrm{O}$ as being clearly distinguishable from $\mathrm{H}_{2} \mathrm{O}$ based on its taste: In open nose taste test 22 out of 28 participants identified the odd sample correctly ( $\mathrm{p}=0.001)$, and in taste only test 14 out of 26 identified the odd sample correctly $(\mathrm{p}=0.03)$. However, in smell-only triangle test, only 9 out of 25 panelists chose the odd sample correctly ( $p>0.05)$. Data are summarized in Figure S1A-C in SM.

Next, the perceived sweetness of $\mathrm{D}_{2} \mathrm{O}$ in increasing proportion to $\mathrm{H}_{2} \mathrm{O}$ was reported using a 9-point scale. $\mathrm{D}_{2} \mathrm{O}$ sweetness was shown to increase in a dose-dependent manner (Figure 2A). The perceived sweetness of increasing concentrations of glucose (Figure 2B), sucrose (Figure 2C), and an artificial sweetener cyclamate (Figure 2D) was tested when dissolved in $\mathrm{H}_{2} \mathrm{O}$ or in $\mathrm{D}_{2} \mathrm{O}$. Pure $\mathrm{D}_{2} \mathrm{O}$ was again perceived as slightly sweet and significantly sweeter than $\mathrm{H}_{2} \mathrm{O}$. Furthermore, $\mathrm{D}_{2} \mathrm{O}$ adds to the sweetness of glucose, cyclamate, and low concentrations of sucrose. 
We then checked whether the effect of $\mathrm{D}_{2} \mathrm{O}$ is sweetness-specific or general, whereby $\mathrm{D}_{2} \mathrm{O}$ might also add intensity to savory taste of umami compounds (MSG) and to bitter taste of bitter compounds (quinine), since these taste modalities are also mediated by GPCR receptors expressed in taste cells. We established here that the intensity of savory taste of MSG in $\mathrm{D}_{2} \mathrm{O}$ did not differ from that in $\mathrm{H}_{2} \mathrm{O}$ (Figure 2E), while the perceived bitterness of quinine was in fact slightly reduced in $\mathrm{D}_{2} \mathrm{O}$ compared to quinine in $\mathrm{H}_{2} \mathrm{O}$ (Figure 2F). This is in agreement with the known effect of sweeteners as maskers of bitter taste, that may be due to both local interactions and sensory integration effects(42-44). Thus, we have ascertained that $\mathrm{D}_{2} \mathrm{O}$ is sweet and adds to sweetness of other sweet molecules, but not to intensity of other GPCR-mediated taste modalities. 
A.

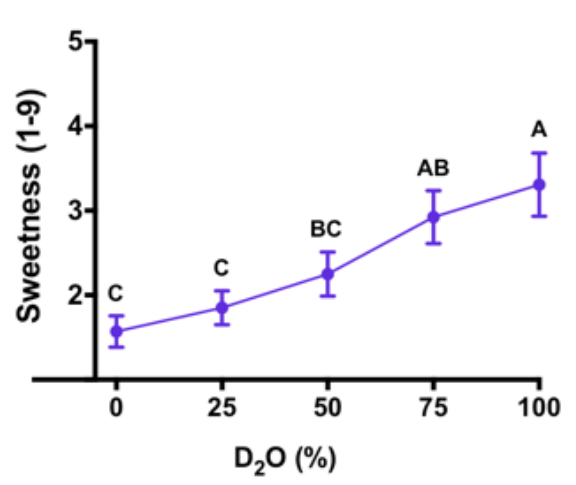

C.

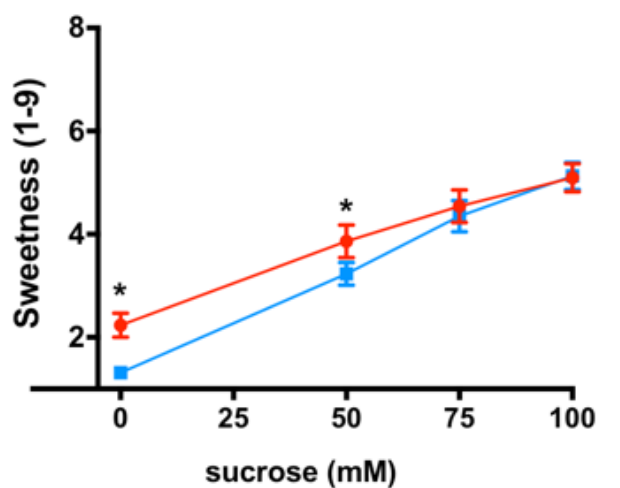

E.

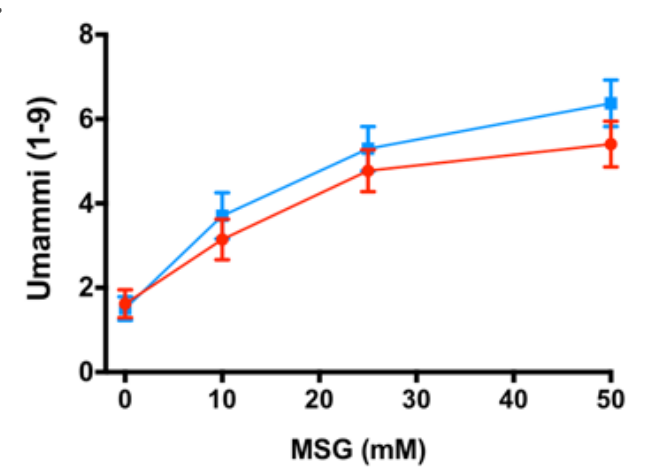

B.

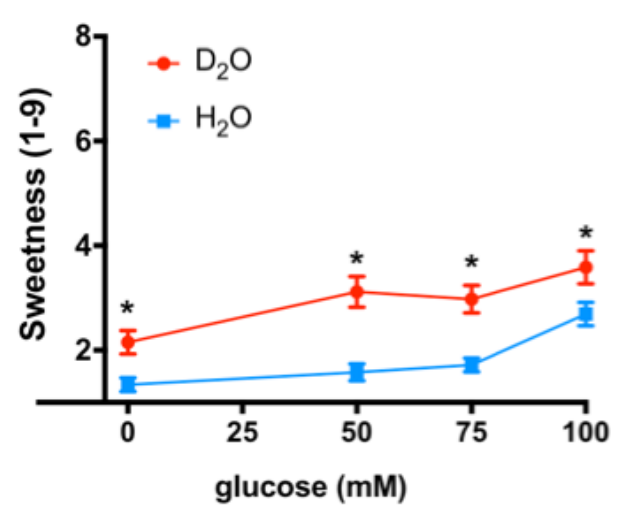

D.

F.
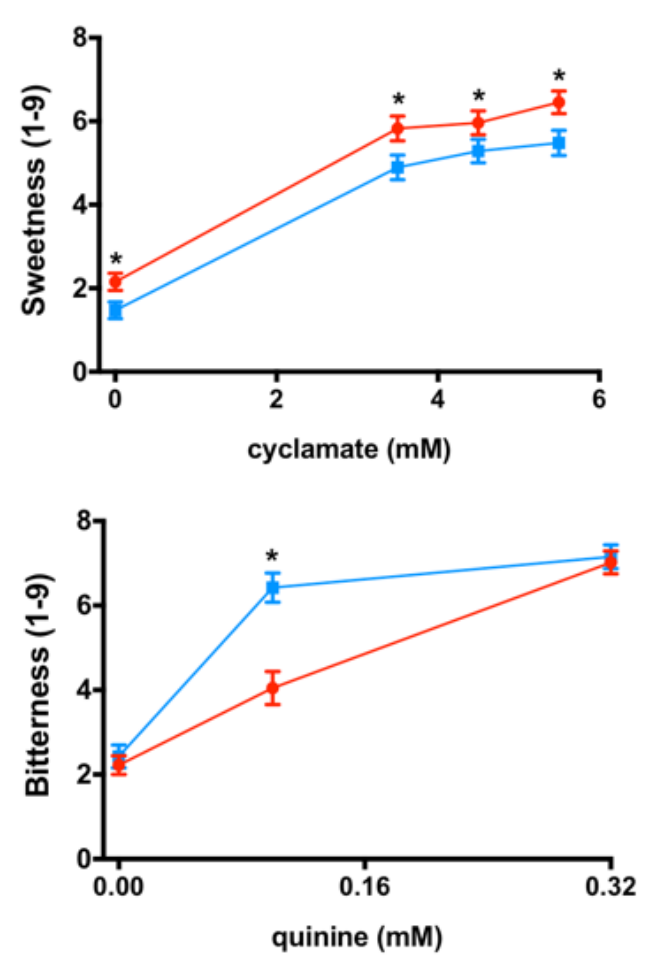

Figure 2. $\mathrm{D}_{2} \mathrm{O}$ sweetness and its effect on different tastants. (A) Sweetness of $\mathrm{D}_{2} \mathrm{O}$ mixed at increasing ratios with $\mathrm{H}_{2} \mathrm{O}$. Treatments not connected by the same letters are significantly different ( $\mathrm{p}<0.05$ in Tuckey Kramer test). (B)-(F) The effect of $\mathrm{D}_{2} \mathrm{O}$ (red) compared to $\mathrm{H}_{2} \mathrm{O}$ (blue) on glucose (B), sucrose (C), cyclamate (D), quinine (E), and MSG (F) taste-specific intensity. Asterisks indicate a significant $(\mathrm{p}<0.05)$ difference between water types using the two-way analysis of variance (ANOVA) with a preplanned comparison t-test. All data are presented as the mean \pm the Standard Error of Measurement (SEM); $\mathrm{n}=15-30$ (4-12 males). The y axis shows the response for individual modalities, while the $\mathrm{x}$ axis is labeled with different water samples. Scale for each modality is labeled as $1=$ no sensation, $3=$ slight, $5=$ moderate, $7=$ very much, and $9=$ extreme sensation. 
bioRxiv preprint doi: https://doi.org/10.1101/2020.05.22.110205; this version posted June 15, 2020. The copyright holder for this preprint (which was not certified by peer review) is the author/funder, who has granted bioRxiv a license to display the preprint in perpetuity. It is made available under aCC-BY-NC-ND 4.0 International license.

\section{Experiments with mice}

Next, we addressed the question whether the sweetness of $\mathrm{D}_{2} \mathrm{O}$ is perceived also by rodents. Lean mice of the C57BL/6J strain were drinking pure $\mathrm{H}_{2} \mathrm{O}, \mathrm{D}_{2} \mathrm{O}$, or a 43 $\mathrm{mmol} / 1 \mathrm{H}_{2} \mathrm{O}$ sucrose solution for $16 \mathrm{~h}$ during a night period. Namely, each of the three groups of mice had a choice from two bottles containing i) $\mathrm{H}_{2} \mathrm{O}$ and $\mathrm{D}_{2} \mathrm{O}$, ii) $\mathrm{H}_{2} \mathrm{O}$ and sucrose solution, or iii) $\mathrm{H}_{2} \mathrm{O}$ and $\mathrm{H}_{2} \mathrm{O}$ (as a control). The food intake was unaffected in all groups (see SM).

A.

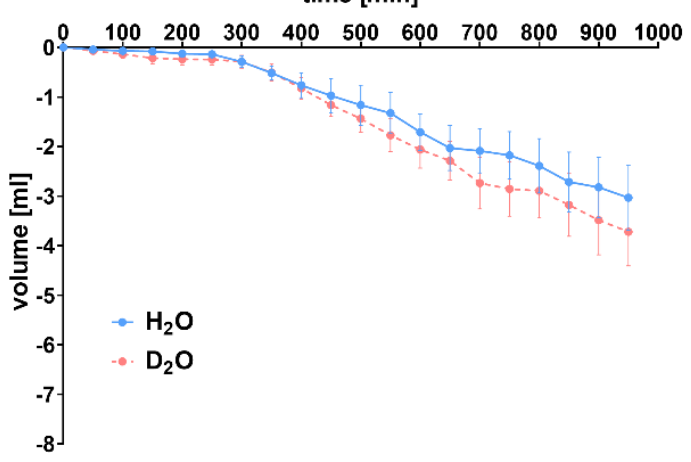

C.

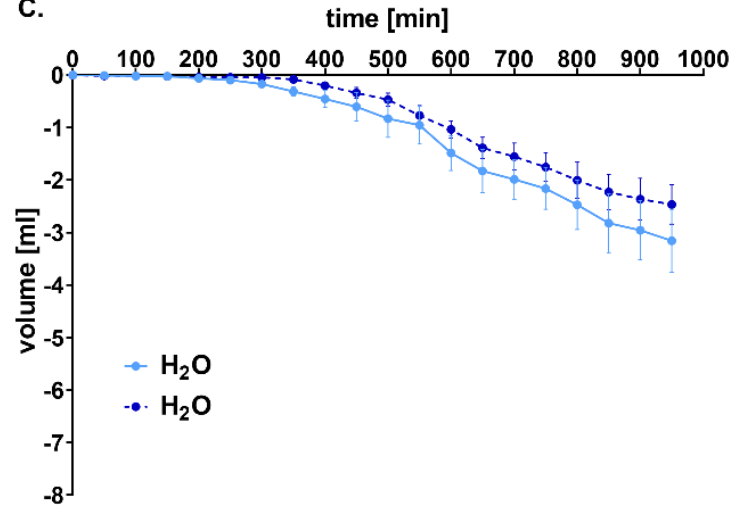

B.

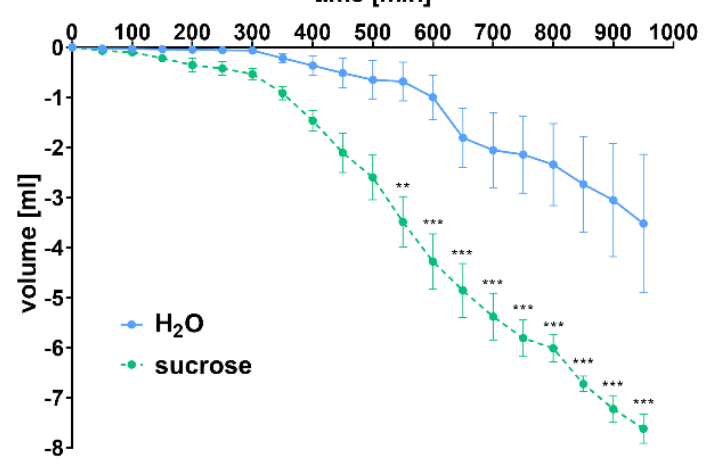

D.

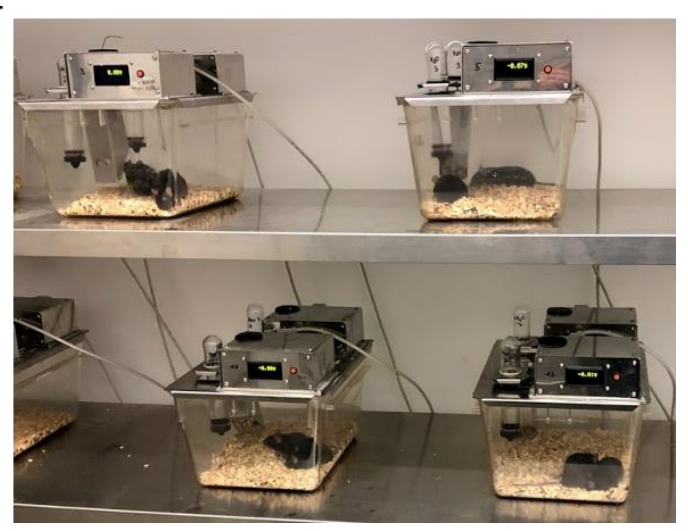

Figure 3. Time-resolved volumes of water consumption by mice. (A) Volume consumption of $\mathrm{D}_{2} \mathrm{O}$ is not different from that of $\mathrm{H}_{2} \mathrm{O}(\mathrm{n}=12)$. (B) Mice show strong preference to sucrose solution $(\mathrm{n}=10)$. Significance is $* * \mathrm{p}<0.01, * * * \mathrm{p}<0.001$. (C) Volume consumption of the control group drinking $\mathrm{H}_{2} \mathrm{O}$ only $(\mathrm{n}=12)$. (D) Snapshot of the automatic drinking monitoring system. Mice were placed in groups of two in individual cages. Data are presented as the mean \pm standard error of the mean (SEM). Statistical analysis was performed using two-way ANOVA with a Bonferroni's multiple comparisons test. 
The results of the drinking experiments are presented in Figures 3A-C, with a snapshot of the experimental setup shown in Figure 3D. In cages where mice were offered both normal water and heavy water (Figure $3 \mathrm{~A}$ ) consumption of $\mathrm{D}_{2} \mathrm{O}$ was within statistical error the same as that of $\mathrm{H}_{2} \mathrm{O}$. Previous reports have shown that on longer timescales than those reported here mice learned to avoid $\mathrm{D}_{2} \mathrm{O}$, as it is poisonous to them in larger quantities(10). It is not clear what is the cue that enables the avoidance learning, but it is evident that the early response to $\mathrm{D}_{2} \mathrm{O}$ is not attractive, suggesting that it is not eliciting sweet taste in mice.

By contrast, mice exhibit a strong preference for sucrose solution over $\mathrm{H}_{2} \mathrm{O}$. Indeed, the consumed volume was significantly increased in line with the predilection of mice for sucrose solutions (Figure 3B). The amount of $\mathrm{H}_{2} \mathrm{O}$ consumed by the control group from either of the two bottles, both containing $\mathrm{H}_{2} \mathrm{O}$, is depicted in Figure $3 \mathrm{C}$. Overall, the data shows that in all three experiments mice consumed comparable amounts of $\mathrm{H}_{2} \mathrm{O}$ and $\mathrm{D}_{2} \mathrm{O}$, with significant increase of consumption of the sucrose solution.

\section{Assessing involvement of TAS1R2/TAS1R3 receptor using human sensory panel}

The chemical dissimilarity of $\mathrm{D}_{2} \mathrm{O}$ from sugars and other sweeteners raises the question whether the effect we observed in human subjects is mediated by TAS1R2/TAS1R3, which is the major receptor for sweet taste(22). This was first explored by combining water samples with lactisole as an established TAS1R2/TAS1R3 inhibitor(30). Using the two-alternative forced choice (2AFC) method, in which the participant must choose between two samples, 18 out of 25 panelists chose pure $\mathrm{D}_{2} \mathrm{O}$ as sweeter than $\mathrm{D}_{2} \mathrm{O}+0.9 \mathrm{mM}$ lactisole solution $(\mathrm{p}<0.05$, Figure $4 \mathrm{~A})$. In an additional experiment, the sweetness of pure $\mathrm{D}_{2} \mathrm{O}$ was scored significantly higher than that of $\mathrm{D}_{2} \mathrm{O}$ 
$+0.9 \mathrm{mM}$ lactisole solution ( $\mathrm{p}=0.0003$ ), while the same amount of lactisole had no effect on the perception of sweetness of $\mathrm{H}_{2} \mathrm{O}$ that served as control (Figure 4B). These results suggest that $\mathrm{D}_{2} \mathrm{O}$ elicits sweetness via the TAS1R2/TAS1R3 sweet taste receptor.

A.

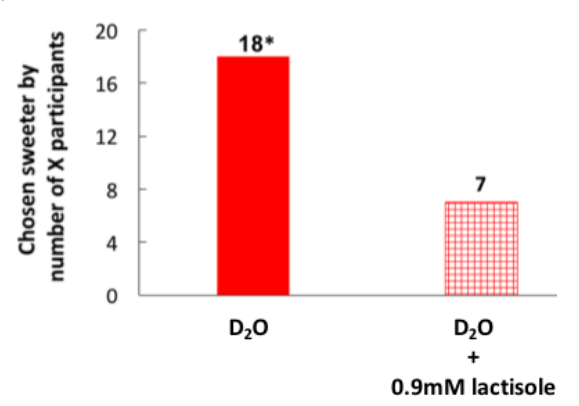

B.

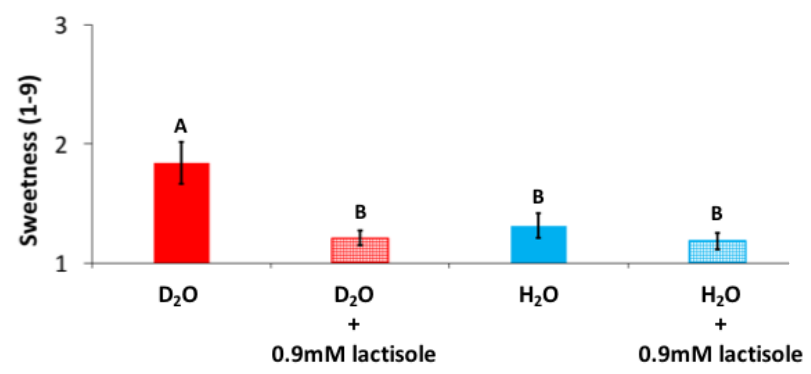

Figure 4. Lactisole reduces sweetness of $\mathrm{D}_{2} \mathrm{O}$. (A) $2 \mathrm{AFC}$ test. Pure $\mathrm{D}_{2} \mathrm{O}$ was chosen to be sweeter $(\mathrm{p}<0.05)$ than the sample with lactisole by 18 participants $(n=25 ; 11$ males $)$. (B) Effect of $0.9 \mathrm{mM}$ lactisole on sweetness intensity using the 9-point scale. Data are presented as the mean \pm SEM. The y axis shows the response for sweetness on a 9-point scale, while the $\mathrm{x}$ axis is labeled with different water samples. Statistical analysis was performed using ANOVA with a Tuckey Kramer test ( $\mathrm{n}=27$; 9 males); treatments not connected by the same letters are significantly different $(\mathrm{p}<0.05)$. Scale for sweetness is labeled as $1=$ no sensation, $3=$ slight, $5=$ moderate, $7=$ very much, and $9=$ extreme sensation.

\section{Cell-based experiments for establishing the role of TAS1R2/TAS1R3}

To confirm the involvement of the sweet taste receptor TAS1R2/TAS1R3 in $\mathrm{D}_{2} \mathrm{O}$ signaling we performed functional calcium mobilization assays using HEK 293 FlpIn TRex cells heterologously expressing both required TAS1R subunits as well as the chimeric $\mathrm{G}$ protein $\mathrm{G} \alpha 15 \mathrm{Gi} 3(45,46)$. As seen in Figure $5, \mathrm{D}_{2} \mathrm{O}$ at $1.85 \mathrm{M}$ and $5.84 \mathrm{M}$ concentrations in $\mathrm{H}_{2} \mathrm{O}$ (3.3\% and $10.4 \%$ respectively) elicited robust responses in TAS1R2/TAS1R3 expressing cells. The strong reduction or absence of $\mathrm{D}_{2} \mathrm{O}$-elicited fluorescence response in the presence of lactisole confirmed the dependence on TAS1R2/TAS1R3. 


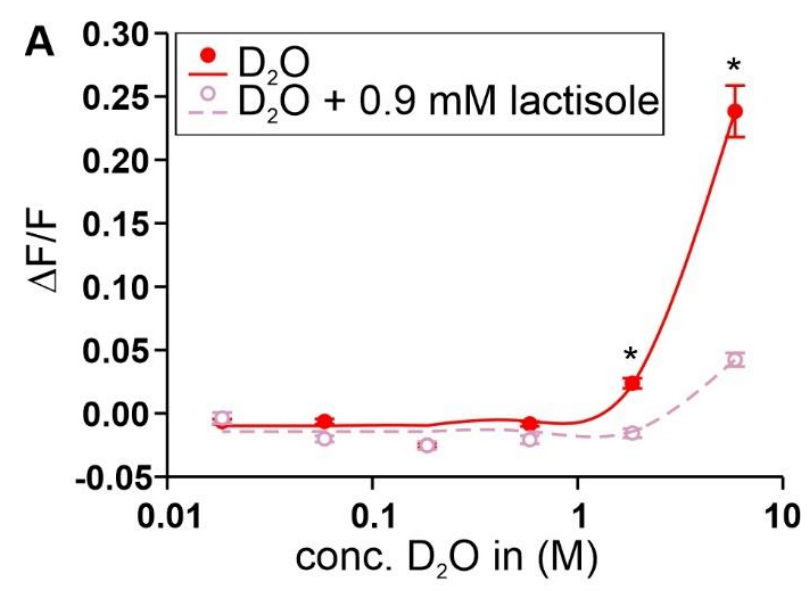

B

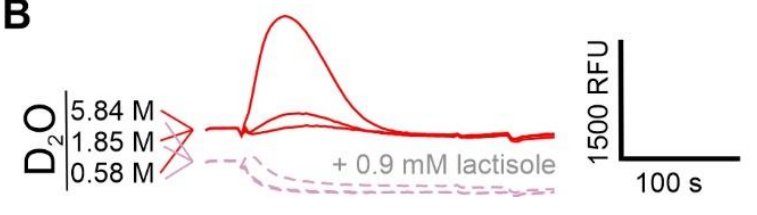

Figure 5. $\mathrm{D}_{2} \mathrm{O}$-activation of the human sweet taste receptor. A) Dose-response relationship of cells expressing the human sweet taste receptor and treated with different concentrations of $\mathrm{D}_{2} \mathrm{O}$ (filled red circles, red line). Cells treated with lactisole served as negative controls (open pink circles, pink line). y-axis, relative changes in fluorescence upon stimulus application $(\Delta \mathrm{F} / \mathrm{F})$. X-axis, logarithmically scaled molar $\mathrm{D}_{2} \mathrm{O}$ concentrations. Asterisks indicate fluorescence changes above baseline significantly different from lactisole-treated controls $(\mathrm{p} \leq 0.01)$. B) Raw fluorescence traces of $\mathrm{D}_{2} \mathrm{O}$ treated (red-traces, top) and $\mathrm{D}_{2} \mathrm{O}+0.9 \mathrm{mM}$ lactisole-treated cells (pink-traces, bottom) stimulated with the indicated $\mathrm{D}_{2} \mathrm{O}$-concentrations. A scale bar indicating relative fluorescence (relative fluorescence units (RFU) and experimental time (in seconds (s)) is included.

We further used an IP1 assay $(47,48)$ on non-transfected HEK293T cells, where we observed that dose-dependent curves of carbachol - an agonist of the endogenous muscarinic receptor $3(\mathrm{M} 3)(49)$ - did not show any difference between $\mathrm{H}_{2} \mathrm{O}$ and $\mathrm{D}_{2} \mathrm{O}$ based media (Figure 6A) and that cell medium that had either $10 \%$ or $100 \% \mathrm{D}_{2} \mathrm{O}$, did not activate basal IP1 accumulation (Figure 6B). Next, TAS1R2/TAS1R3 receptor along 
with the chimeric Gal6gust44 subunit(46, 50) were transiently expressed, and the functionality was illustrated by dose-dependent response to D-glucose (Figure 6C). Finally, and in agreement with calcium imaging, we found that $10 \% \mathrm{D}_{2} \mathrm{O}$ activated these cells. Activation by $100 \% \mathrm{D}_{2} \mathrm{O}$ was even more pronounced (Figure 6D).
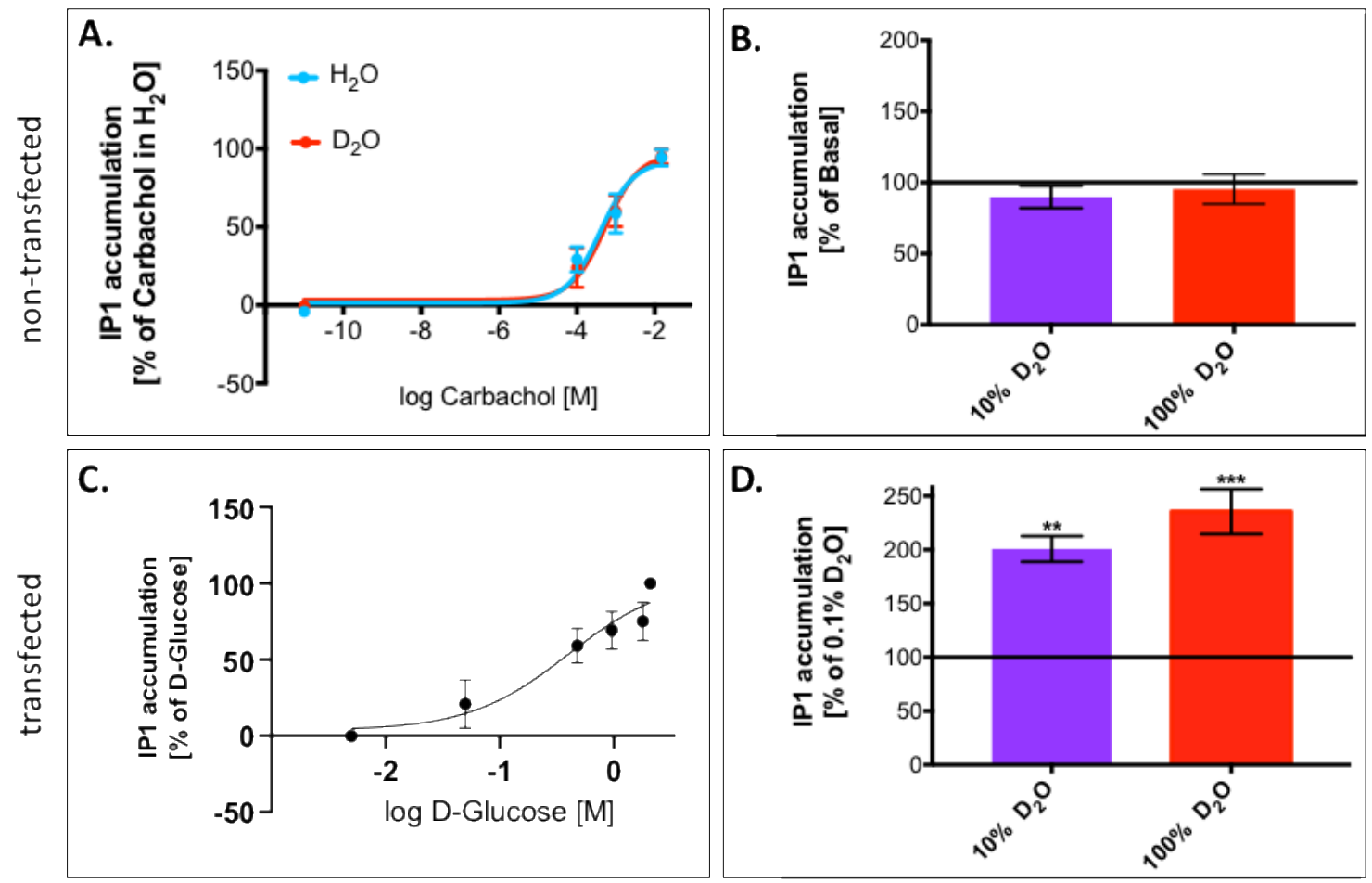

Figure 5. IP1 accumulation in HEK 293T cells following exposure to different ligands dissolved in powder-based DMEM medium. (A) Non-transfected HEK 293T cells respond similarly to raising concentrations of carbachol dissolved in $\mathrm{D}_{2} \mathrm{O}$ (red) as in $\mathrm{H}_{2} \mathrm{O}$ (blue). (B) $\mathrm{D}_{2} \mathrm{O}$ caused no elevation of IP1 levels in non-transfected HEK 293T cells. (C) HEK 293T cells transiently expressing TAS1R2/TAS1R3 respond positively to Dglucose. (D) Transfected HEK $293 \mathrm{~T}$ cells are activated by $\mathrm{D}_{2} \mathrm{O}$. Values represent the mean \pm SEM of at least 3 replicates. The horizontal black line represents the basal values of controls. Significant differences in IP1 values from control values are marked with ** for $\mathrm{p} \leq 0.005$ and $* * *$ for $\mathrm{p} \leq 0.0005$ using Dunnett's multiple comparisons test. 


\section{Molecular modelling}

The cellular response results further support the hypothesis that the sweet taste of $\mathrm{D}_{2} \mathrm{O}$ is mediated via the TAS1R2/TAS1R3 receptor. Various mechanisms governing this effect can be envisioned. As a potential suspect, we focus on a direct effect on the sweet taste receptor, narrowing on the TAS1R3 TMD (see Figure 1), as it is already known to be a modulation site with functional differences between humans and rodents $(23,29,30)$. Furthermore, water-binding sites were discovered at the TMD of many $\operatorname{GPCRs}(51,52)$, suggesting a potential target for $\mathrm{D}_{2} \mathrm{O}$ binding. We modeled the human TAS1R3 TMD using the I-TASSER server(31). Positions of $\mathrm{H}_{2} \mathrm{O}$ molecules were compared among mGluR5 structures (PDB: 4OO9, 5CGC, and 5CGD) and two conserved positions were found. The $\mathrm{H}_{2} \mathrm{O}$ molecules in these two positions were merged with the TAS1R3 model and minimized (Figure 7A). The water mapping protocol from OpenEye(53) enables mapping of water positions based on the energetics of water, and $\sim 40$ water molecules were predicted in the binding site using this protocol (Figure 7A). Water densities of $\mathrm{H}_{2} \mathrm{O}$ and $\mathrm{D}_{2} \mathrm{O}$ in the TMD of the TAS1R2/TAS1R3 receptor were calculated from MD simulations as described below. Overall, all three methods suggest the possibility for at least some internal molecules (trapped in the TMD bundle) in addition to water that surrounds the extracellular and intracellular loops (Figure 7A). 
A.
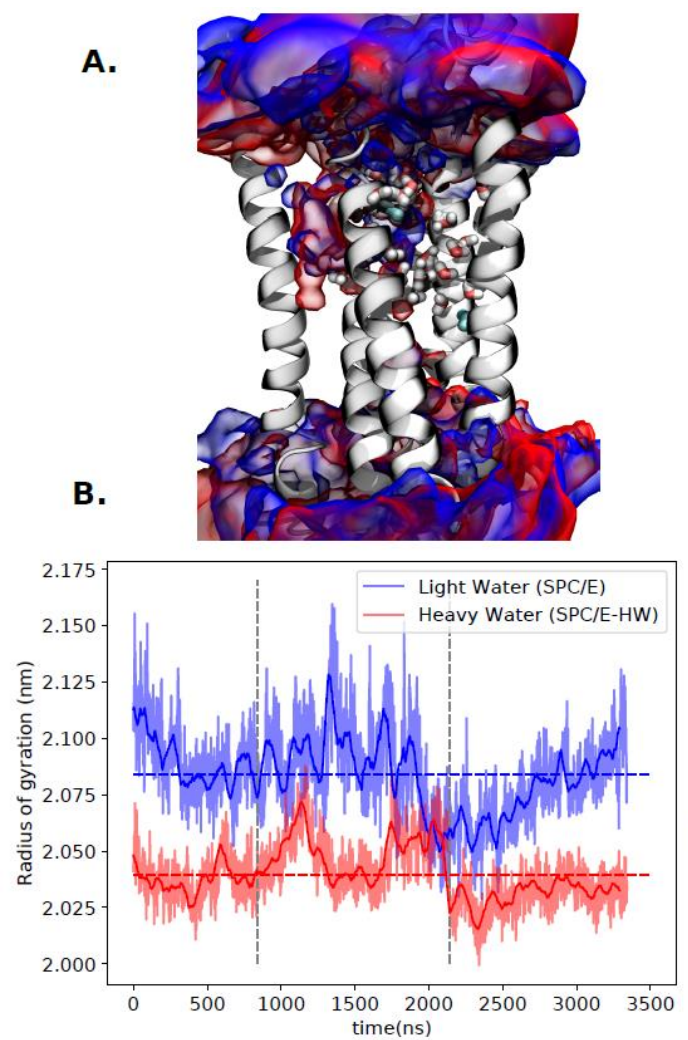

C.

D.
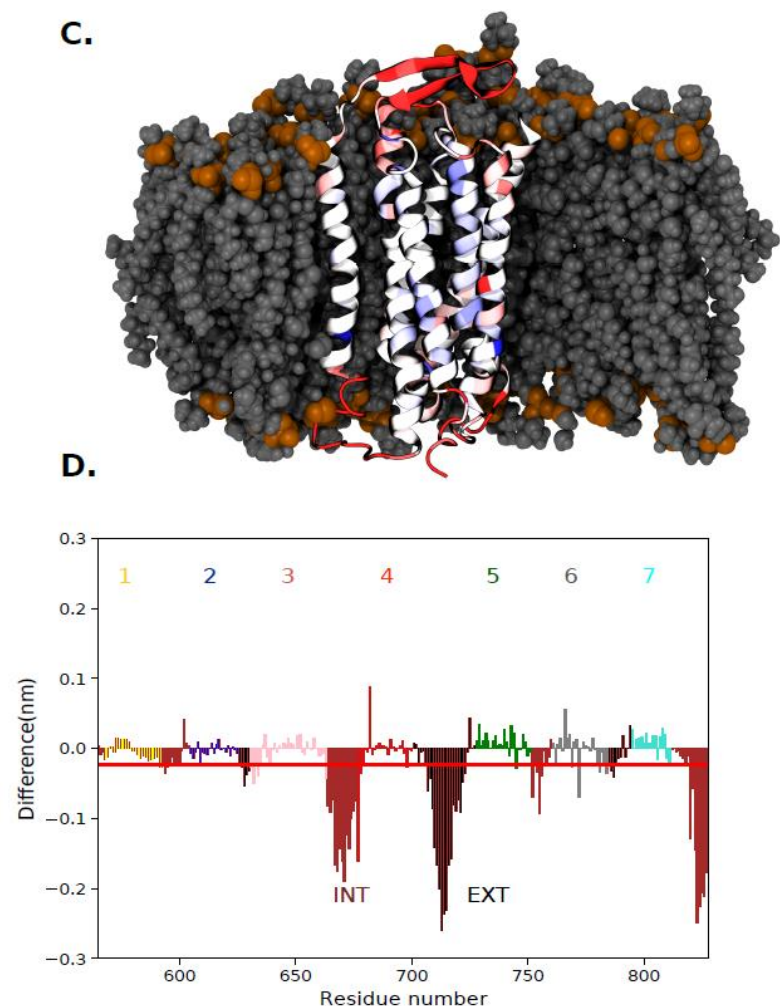

Figure 7: Differences between the behavior of the trans-membrane part of the human sweet taste receptor in $\mathrm{H}_{2} \mathrm{O}$ vs $\mathrm{D}_{2} \mathrm{O}$ base on analysis of three independent microsecond trajectories. (A) Structure of the TMD of the TAS1R2/TAS1R3 receptor with the probability density (volumetric map) of $\mathrm{H}_{2} \mathrm{O}$ (blue) or $\mathrm{D}_{2} \mathrm{O}$ (red) molecules within $10 \AA$ from the protein evaluated using the VMD VolMap tool from the MD simulations at an isovalue of 0.1. The conserved water molecules in the X-ray templates are shown in cyan color. Water molecules predicted with the software OpenEye(53) are shown in licorice representation. (B) Time evolution of the radii of gyration in $\mathrm{H}_{2} \mathrm{O}$ (blue) and $\mathrm{D}_{2} \mathrm{O}$ (red) from three microsecond-timescale simulations (separated by vertical dashed lines) with total mean values as dashed lines, showing that the protein is more compact in heavy water. (C) Representative snapshot of the trans-membrane part of the human sweet taste receptor color-coded that red/blue represents parts more/less rigid in $\mathrm{D}_{2} \mathrm{O}$ vs $\mathrm{H}_{2} \mathrm{O}$. The embedding lipid membrane is represented in gray. (D) Difference in root mean square fluctuations in MD trajectories. Negative/positive values mean that structures are more/less rigid in $\mathrm{D}_{2} \mathrm{O}$ than in $\mathrm{H}_{2} \mathrm{O}$. The red line represents the sum over all residues.

Next, we carried out microsecond MD simulations of the TMD embedded in a phospatidylcholine (POPC) bilayer in either $\mathrm{H}_{2} \mathrm{O}$ or $\mathrm{D}_{2} \mathrm{O}$ (for details including our model of $\mathrm{D}_{2} \mathrm{O}$ effectively including nuclear quantum effects see $\left.\mathrm{SM}\right)$. Note that water molecules enter the TMD domain and cluster at positions that partially overlap with the modeled 
water positions, see Figure 7A. More precisely, $\mathrm{H}_{2} \mathrm{O}$ and $\mathrm{D}_{2} \mathrm{O}$ have mutually slightly shifted densities inside the protein cavity, with $\mathrm{H}_{2} \mathrm{O}$ overlapping better than $\mathrm{D}_{2} \mathrm{O}$ with the modeled water positions. Furthermore, MD simulations show clustered water molecules close to the lactisole binding site. These internal positions may have a differential effect between $\mathrm{H}_{2} \mathrm{O}$ and $\mathrm{D}_{2} \mathrm{O}$, though differences between the averaged water densities are not very pronounced. Figure 7B shows the time evolution of the radius of gyration of the TMD domain, while Figures 7C and 7D presents the root mean square fluctuations (RMSF) of individual residues of the proteins superimposed on its structure and plotted in a graph together with the mean value of RMSF. A small but significant difference is apparent in the behavior of the protein in $\mathrm{H}_{2} \mathrm{O}$ vs $\mathrm{D}_{2} \mathrm{O}$. Namely, structural fluctuations of most residues (particularly those directly exposed to the aqueous environment) and of the protein as a whole are slightly attenuated in $\mathrm{D}_{2} \mathrm{O}$, in which environment the protein is also somewhat more compact than in $\mathrm{H}_{2} \mathrm{O}$ (Figure 7B). Additional simulations on other representative systems show that the rigidifying effect of heavy water is apparent also in small soluble proteins (see SM).

\section{Summary and outlook}

In summary, we have systematically addressed the question of the sweet taste of heavy water. Importantly, by employing gas chromatography/mass spectrometry analysis we demonstrate that the effect is not due to impurities. Being only isotopically different from $\mathrm{H}_{2} \mathrm{O}$, in principle, $\mathrm{D}_{2} \mathrm{O}$ should be indistinguishable from $\mathrm{H}_{2} \mathrm{O}$ with regard to taste, namely it should have no taste of its own. $\mathrm{H}_{2} \mathrm{O}$ was shown previously to elicit sweet taste by rinsing sweet taste inhibitors away, both in human sensory experiments and in cellbased studies, which was explained in terms of a two-state model, where the receptor 
shifts to its activated state when released from inhibition by rinsing with water (45). Here, we have studied the taste of $\mathrm{D}_{2} \mathrm{O}$ and $\mathrm{H}_{2} \mathrm{O}$ per se, not related to washing away of sweet taste inhibitors. Using psychophysics protocols, we show that humans differentiate between $\mathrm{D}_{2} \mathrm{O}$ and $\mathrm{H}_{2} \mathrm{O}$ based on taste. Next, we illustrate that human subjects consistently perceive $\mathrm{D}_{2} \mathrm{O}$ as being mildly sweet and significantly sweeter than $\mathrm{H}_{2} \mathrm{O}$. Moreover, $\mathrm{D}_{2} \mathrm{O}$ added to sweetness of some sweeteners; sweetness of glucose and cyclamate appears to be directly additive, while in the case of sucrose the additive effect was observed only at $50 \mathrm{mM}$ sugar concentration. Furthermore, $\mathrm{D}_{2} \mathrm{O}$ did not enhance the umami taste perception of MSG, and reduced the perceived bitterness of $0.1 \mathrm{mM}$ quinine, in agreement with the known effect of bitterness suppression by sweet molecules.

A further important funding is that lactisole, which is an established blocker of the TAS1R2/TAS1R3 sweet taste receptor that acts at the TAS1R3 transmembrane domain(30), suppresses both the sweet perception of $\mathrm{D}_{2} \mathrm{O}$ in sensory tests and the activation of TAS1R/TAS1R3 in calcium imaging assay. In support of these observations cell-based experiments demonstrate that HEK 293T cells transfected with TAS1R2/TAS1R3 and Ga16gust44 chimera, but not the non-transfected cells, are activated by $\mathrm{D}_{2} \mathrm{O}$, as measured by IP1 accumulation compared to control values. Finally, taste experiments on mice show that these animals do not prefer $\mathrm{D}_{2} \mathrm{O}$ over $\mathrm{H}_{2} \mathrm{O}$.

Our findings point to the human sweet taste receptor TAS1R2/TAS1R3 as being essential for sweetness of $\mathrm{D}_{2} \mathrm{O}$. Molecular dynamics simulations show, in agreement with experiment(38), that proteins in general are slightly more rigid and compact in $\mathrm{D}_{2} \mathrm{O}$ than in $\mathrm{H}_{2} \mathrm{O}$. At a molecular level, this general behavior may be traced back to the slightly stronger hydrogen bonding in $\mathrm{D}_{2} \mathrm{O}$ vs $\mathrm{H}_{2} \mathrm{O}$, which is due to a nuclear quantum effect, 
namely difference in zero-point energy $(3,4)$. Biologically relevant situations where one may expect strong nuclear quantum effects as implications of H/D substitution directly involve proton or deuteron transfer (9). Unless a yet unknown indirect mechanism is involved, this is not the case for the TAS1R2/TAS1R3 sweet taste receptor, thus the nuclear quantum effect is probably weak in the present case. Future studies should be able to elucidate the precise sites and mechanisms of action, as well as the reason why $\mathrm{D}_{2} \mathrm{O}$ activates TAS1R2/TAS1R3 in particular, resulting in sweet (but not other) taste. To this end, site directed mutagenesis as well as determination of the precise structure of the TAS1R2/TAS1R3 receptor will be of a key importance.

\section{Acknowledgment}

We thank R. F. Margolskee for the pcDNA of chimeric Ga16gust44 and P. Jiang and Y. Wang for hosting N.B.A. in Monell Chemical Senses Center during preliminary stages of this project. V.P. and L.M. acknowledge Ondřej Pačes and his team for the development of automatic drinking monitoring system, and Hedvika Vysušilová for outstanding technical assistance and animal handling. M.B. thanks Catherine Delaporte for excellent technical assistance. P.J. thanks the European Regional Development Fund OP RDE (project ChemBioDrug no. CZ.02.1.01/0.0/0.0/16_019/0000729) for support. Funding by ISF grant \#1129/19 and UHJFrance and the Foundation Scopus to M.Y.N. is gratefully acknowledged. M.Y.N. is a member of COST actions Mu.Ta.Lig (CA15135) and ERNEST (CA18133). P.E.M. acknowledges support from his popular science YouTube channel.

Author contributions: NBA, PEM, MYN, and PJ designed the study, NBA and HK performed sensory experiments, NBA and EM carried out IP1 experiments, MB conducted calcium imaging experiments, ND and YBSG performed homology modeling and structural analyses, PEM 
bioRxiv preprint doi: https://doi.org/10.1101/2020.05.22.110205; this version posted June 15, 2020. The copyright holder for this preprint (which was not certified by peer review) is the author/funder, who has granted bioRxiv a license to display the preprint in perpetuity. It is made available under aCC-BY-NC-ND 4.0 International license.

performed water purification, JC performed water purity tests, VP and LM performed experiments on mice, VCC developed the heavy water interaction potential, and CT performed the molecular dynamics simulations. PJ, MYN, and NBA wrote the paper with input from all coauthors. 


\section{References}

1. H. C. Urey, F. G. Brickwedde, G. M. Murphy, A Hydrogen Isotope of Mass 2. Physical Review 39, 164-165 (1932).

2. M. Francl, The weight of water. Nature Chemistry 11, 284-285 (2019).

3. T. Clark, J. Heske, T. D. Kühne, Opposing Electronic and Nuclear Quantum Effects on Hydrogen Bonds in H2O and D2O. ChemPhysChem 20, 2461-2465 (2019).

4. F. Paesani, G. A. Voth, The Properties of Water: Insights from Quantum Simulations. The Journal of Physical Chemistry B 113, 5702-5719 (2009).

5. F. Macdonald, D. R. Lide, CRC handbook of chemistry and physics: From paper to web. Abstr Pap Am Chem S 225, U552-U552 (2003).

6. R. A. J. Bogan, S. Ohde, T. Arakaki, I. Mori, C. W. McLeod, Changes in Rainwater pH associated with Increasing Atmospheric Carbon Dioxide after the Industrial Revolution. Water, Air, and Soil Pollution 196, 263-271 (2009).

7. E. Van Horn, G. C. Ware, Growth of Bacterium coli and Staphylococcus albus in Heavy Water. Nature 184, 833-833 (1959).

8. O. Mosin, I. Ignatov, D. Skladnev, V. Shvets, Studying of Phenomenon of Biological Adaptation to Heavy Water. European Journal of Molecular Biotechnology 6, (2014).

9. C. Kampmeyer et al., Mutations in a Single Signaling Pathway Allow Cell Growth in Heavy Water. Acs Synthetic Biology 9, 733-748 (2020).

10. H. G. Barbour, The Basis of the Pharmacological Action of Heavy Water in Mammals. Yale J Biol Med 9, 551-565 (1937).

11. D. M. Czajka, A. J. Finkel, C. S. Fischer, J. J. Katz, Physiological effects of deuterium on dogs. American Journal of Physiology-Legacy Content 201, 357-362 (1961).

12. W. Dansgaard, STABLE ISOTOPES IN PRECIPITATION. Tellus 16, 436-468 (1964).

13. P. J. H. Jones, S. T. Leatherdale, Stable isotopes in clinical research: safety reaffirmed. Clinical Science 80, 277-280 (1991).

14. J. Speakman, Speakman JR. The history and theory of the doubly labeled water technique. Am J Clin Nutr 68, 932S-938S. The American journal of clinical nutrition 68, 932S-938S (1998).

15. C. S. Pittendrigh, P. C. Caldarola, E. S. Cosbey, A Differential Effect of Heavy Water on Temperature-Dependent and Temperature-Compensated Aspects of the Circadian System of \&lt;em\&gt;Drosophila pseudoobscura\&lt;/em\&gt. Proceedings of the National Academy of Sciences 70, 2037 (1973).

16. C. P. Richter, Heavy water as a tool for study of the forces that control length of period of the 24-hour clock of the hamster. Proc Natl Acad Sci U S A 74, 1295-1299 (1977).

17. K. Hansen, E. Rustung, Untersuchen uber die Biologische Wirkungen von "Schwerem Wasser" bei Warmblutigen Tieren. Klinische Wochenschrift 14, 104-108 (1935).

18. H. C. Urey, G. Failla, Concerning the taste of heavy water. Science 81, 273 (1935).

19. R. H. Kirby, D. F. Pick, M. S. Riddick, Discrimination between heavy water and deionized water using gustation vs. olfaction in humans. Physiological Psychology 4, 102-104 (1976).

20. C. P. Richter, STUDY OF TASTE AND SMELL OF HEAVY-WATER (99.8PERCENT) IN RATS. Proceedings of the Society for Experimental Biology and Medicine 152, 677-684 (1976).

21. I. J. Miller, G. Mooser, TASTE RESPONSES TO DEUTERIUM-OXIDE. Physiology \& Behavior 23, 69-74 (1979).

22. G. Nelson et al., Mammalian Sweet Taste Receptors. Cell 106, 381-390 (2001).

23. X. Li et al., Human receptors for sweet and umami taste. Proceedings of the National Academy of Sciences 99, 4692 (2002).

24. A. Di Pizio, M. Y. Niv, Computational Studies of Smell and Taste Receptors. Israel Journal of Chemistry 54, 1205-1218 (2014).

25. R. Gutierrez, E. Fonseca, S. A. Simon, The neuroscience of sugars in taste, gut-reward, feeding circuits, and obesity. Cellular and Molecular Life Sciences, (2020).

26. S. Damak et al., Detection of Sweet and Umami Taste in the Absence of Taste Receptor T1r3 Science 301, 850-853 (2003).

27. K. K. Yee, S. K. Sukumaran, R. Kotha, T. A. Gilbertson, R. F. Margolskee, Glucose transporters 
and ATP-gated $\mathrm{K}+(\mathrm{KATP})$ metabolic sensors are present in type 1 taste receptor 3 (T1r3)expressing taste cells. Proc Natl Acad Sci U S A 108, 5431-5436 (2011).

28. A. A. Bachmanov, M. G. Tordoff, G. K. Beauchamp, Sweetener preference of C57BL/6ByJ and 129P3/J mice. Chem Senses 26, 905-913 (2001).

29. P. Jiang et al., Identification of the Cyclamate Interaction Site within the Transmembrane Domain of the Human Sweet Taste Receptor Subunit T1R3. Journal of Biological Chemistry 280, 34296-34305 (2005).

30. P. Jiang et al., Lactisole Interacts with the Transmembrane Domains of Human T1R3 to Inhibit Sweet Taste. Journal of Biological Chemistry 280, 15238-15246 (2005).

31. J. Yang, Y. Zhang, I-TASSER server: new development for protein structure and function predictions. Nucleic Acids Res 43, W174-181 (2015).

32. Y. Ben Shoshan-Galeczki, M. Y. Niv, Structure-based screening for discovery of sweet compounds. Food Chemistry 315, 126286 (2020).

33. T. D. Goddard et al., UCSF ChimeraX: Meeting modern challenges in visualization and analysis. Protein Sci 27, 14-25 (2018).

34. G. Q. Zhao et al., The Receptors for Mammalian Sweet and Umami Taste. Cell 115, 255-266 (2003).

35. N. Chaudhari, S. D. Roper, The cell biology of taste. J Cell Biol 190, 285-296 (2010).

36. A. Dagan-Wiener et al., BitterDB: taste ligands and receptors database in 2019. Nucleic Acids Research 47, D1179-D1185 (2019).

37. A. Dagan-Wiener et al., Bitter or not? BitterPredict, a tool for predicting taste from chemical structure. Scientific Reports 7, 12074 (2017).

38. P. Cioni, G. B. Strambini, Effect of heavy water on protein flexibility. Biophys J 82, 3246-3253 (2002).

39. S. Gane et al., Molecular Vibration-Sensing Component in Human Olfaction. PLOS ONE 8, e55780 (2013).

40. E. Block, S. Jang, H. Matsunami, V. S. Batista, H. Zhuang, Reply to Turin et al.: Vibrational theory of olfaction is implausible. Proceedings of the National Academy of Sciences 112, E3155 (2015).

41. L. B. Vosshall, Laying a controversial smell theory to rest. Proceedings of the National Academy of Sciences 112, 6525 (2015).

42. J. A. Mennella, D. R. Reed, P. S. Mathew, K. M. Roberts, C. J. Mansfield, “A Spoonful of Sugar Helps the Medicine Go Down": Bitter Masking by Sucrose Among Children and Adults. Chem Senses 40, 17-25 (2014).

43. N. Ben Abu, D. Harries, H. Voet, M. Y. Niv, The taste of $\mathrm{KCl}$ - What a difference a sugar makes. Food Chemistry 255, 165-173 (2018).

44. N. Dubovski, E. Ert, M. Niv, Bitter mouth-rinse affects emotions. Food Quality and Preference 60, (2017).

45. V. Galindo-Cuspinera, M. Winnig, B. Bufe, W. Meyerhof, P. A. S. Breslin, A TAS1R receptorbased explanation of sweet 'water-taste'. Nature 441, 354-357 (2006).

46. M. Behrens, K. Blank, W. Meyerhof, Blends of Non-caloric Sweeteners Saccharin and Cyclamate Show Reduced Off-Taste due to TAS2R Bitter Receptor Inhibition. Cell Chemical Biology 24, 1199-+ (2017).

47. E. Trinquet et al., d-myo-Inositol 1-phosphate as a surrogate of d-myo-inositol 1,4,5-tris phosphate to monitor $\mathrm{G}$ protein-coupled receptor activation. Analytical Biochemistry 358, 126135 (2006).

48. R. Zhang, X. Xie, Tools for GPCR drug discovery. Acta Pharmacol Sin 33, 372-384 (2012).

49. G. P. Hussmann, R. P. Yasuda, Y. Xiao, B. B. Wolfe, K. J. Kellar, Endogenously expressed muscarinic receptors in HEK293 cells augment up-regulation of stably expressed $\alpha 4 \beta 2$ nicotinic receptors. J Biol Chem 286, 39726-39737 (2011).

50. T. Ueda, S. Ugawa, H. Yamamura, Y. Imaizumi, S. Shimada, Functional interaction between T2R taste receptors and G-protein alpha subunits expressed in taste receptor cells. Journal of Neuroscience 23, 7376-7380 (2003).

51. J. S. Mason, A. Bortolato, M. Congreve, F. H. Marshall, New insights from structural biology into the druggability of G protein-coupled receptors. Trends Pharmacol Sci 33, 249-260 (2012). 
bioRxiv preprint doi: https://doi.org/10.1101/2020.05.22.110205; this version posted June 15, 2020. The copyright holder for this preprint (which was not certified by peer review) is the author/funder, who has granted bioRxiv a license to display the preprint in perpetuity. It is made available under aCC-BY-NC-ND 4.0 International license.

52. A. J. Venkatakrishnan et al., Diverse GPCRs exhibit conserved water networks for stabilization and activation. Proc Natl Acad Sci U S A 116, 3288-3293 (2019).

53. A. S. Bayden, D. T. Moustakas, D. Joseph-McCarthy, M. L. Lamb, Evaluating Free Energies of Binding and Conservation of Crystallographic Waters Using SZMAP. Journal of Chemical Information and Modeling 55, 1552-1565 (2015).

54. V. Galindo-Cuspinera, P. A. S. Breslin, The Liaison of Sweet and Savory. Chem Senses 31, 221225 (2005).

55. S. Sutton, Encyclopedia of Research Design. Libr J 135, 105-106 (2010).

56. S. E. Kemp, T. Hollowood, J. Hort, Sensory evaluation : a practical handbook. (Ames WileyBlackwell, Chichester, U.K. ;, 2009), pp. xi, 196 p.

57. B. G. Green, G. S. Shaffer, M. M. Gilmore, Derivation and Evaluation of a Semantic Scale of Oral Sensation Magnitude with Apparent Ratio Properties. Chem Senses 18, 683-702 (1993).

58. A. Sclafani, C. Perez, Cypha(TM) propionic acid, 2-(4-methoxyphenol) salt inhibits sweet taste in humans, but not in rats. Physiology \& Behavior 61, 25-29 (1997).

59. G. G. G. G. Krivov, M. V. Shapovalov, J. R. L. Dunbrack, R.L., Improved Prediction of Protein Side-Chain Conformations With SCWRL4 Proteins 77, 778-795 (2009).

60. J. R. Grigera, An effective pair potential for heavy water. Journal of Chemical Physics 114, 8064-8067 (2001).

61. W. G. Hoover, Canonical dynamics: Equilibrium phase-space distributions. Physical Review A 31, 1695-1697 (1985).

62. M. Parrinello, A. Rahman, Polymorphic transitions in single crystals: A new molecular dynamics method. Journal of Applied Physics 52, 7182-7190 (1981).

63. B. Hess, Determining the shear viscosity of model liquids from molecular dynamics simulations. The Journal of Chemical Physics 116, 209-217 (2002).

64. S. Pronk et al., GROMACS 4.5: a high-throughput and highly parallel open source molecular simulation toolkit. Bioinformatics 29, 845-854 (2013).

65. H. J. C. Berendsen, J. R. Grigera, T. P. Straatsma, The Missing Term in Effective Pair Potentials. Journal of Physical Chemistry 91, 6269-6271 (1987).

66. J. Huang et al., CHARMM36m: an improved force field for folded and intrinsically disordered proteins. Nature Methods 14, 71-73 (2017). 